\title{
The Evaluation of Dentists' Awareness and Knowledge in Turkey Regarding Bisphosphonates
}

\section{Türkiye'de Diş Hekimlerinin Bifosfonatlar Konusundaki Farkındalık Ve Bilgilerinin Değerlendirilmesi}

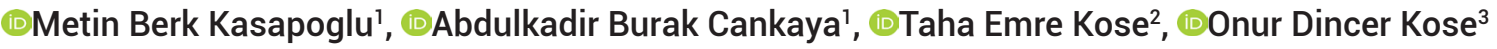 \\ (1) Belde Arsan ${ }^{4}$, (DAhmet Taylan Cebi ${ }^{5}$, (1) Mehmet Ali Erdem \\ Iİstanbul Üniversitesi Diş Hekimliği Fakültesi, Ağız Diş ve Çene Cerrahisi Anabilim Dalı, Istanbul, Turkey \\ ${ }^{2}$ Recep Tayyip Erdoğan Üniversitesi, Diş Hekimliği Fakültesi, Ağız Diş ve Çene Radyolojisi Anabilim Dalı, Rize, Turkey \\ ${ }^{3}$ Rize Ağız ve Diş Sağlığı Merkezi, Rize, Turkey \\ ${ }^{4}$ İstanbul Medeniyet Üniversitesi, Diş Hekimliği Fakültesi Ağız Diş ve Çene Radyolojisi Anabilim Dalı, Istanbul, Turkey \\ ${ }^{5}$ Karabük Üniversitesi Diş Hekimliği Fakültesi Ağız Diş ve Çene Cerrahisi Anabilim Dalı, Karabuk, Turkey
}

Copyright@Author(s) - Available online at www.dergipark.org.tr/tr/pub/medr

Content of this journal is licensed under a Creative Commons Attribution-NonCommercial 4.0 International License.

\begin{abstract}
Aim: Bisphosphonates (BPs) are inorganic pyrophosphate analogs used for the treatment of various diseases. This study aimed to evaluate the knowledge and attitudes of general dental practitioners (GDP), specialist trainees (ST), and specialists (S) in Turkey toward medication-related osteonecrosis of the jaw (MRONJ) and to optimize future training programs in this field.

Materials and Methods: A self-report questionnaire consisting of 7 questions about demographic data, knowledge about BPs, MRONJ and treatment modalities was prepared and send to the members of Turkish Dental Association via email.

Results: A total of 209 participants were included in this survey. The mean age of the ST group was significantly lower than the mean ages of the GDP and $S$ groups $(P=0.003, P=0.038)$. GDP are less likely to think of BPs administration and radiotherapy treatment than $S$ or ST upon observation of an exposed bone in the head-and-neck region $(P=0.048, P=0.008)$. In comparison to the $S$ and $S T$ groups, the GDP group displayed less knowledge regarding the radiological and intraoral examination of patients undergoing $\mathrm{BP}$ therapy $(\mathrm{P}=$ 0.034).

Conclusion: The increasing awareness of dentists about usage and side effects of BPs is important for preventing MRONJ. The GDP group displayed significantly less knowledge regarding the radiological and intraoral examinations of patients undergoing BP therapy. Greater efforts are required to increase education and knowledge of MRONJ and BPs among dental practitioners.
\end{abstract}

Key words: Medication-related osteonecrosis of the jaw; bisphosphonates, dentists; preventive dentistry; survey

Öz

Amaç: Bisfosfonatlar çeşitli hastalıkların tedavisinde kullanılan inorganik pirofosfat analoglarıdır. Bu çalışma uzman olmayan diş hekimlerinin, uzmanlık öğrencilerinin ve uzmanların ilaca bağlı gelişen çene osteonekrozuna yönelik bilgi ve tutumlarını değerlendirmenin yanında, gelecekteki eğitim programlarını optimize etmeyi amaçlamıştır.

Materyal ve Metot: Çalışmaya 209 katılımcı dahil edilmiştir. Türk Dişhekimleri Birliği'nin desteğiyle bir anket hazırlanmış ve üyeler arasında e-posta ile paylaşılmıştır. Katılımcıların demografık bilgiler, ilaca bağlı çene osteonekrozları, bisfosfonatlar ve tedavi yaklaşımları ile ilgili 7 sorudan oluşan anketi yanıtlamaları istenmiştir. Bu anket sorularına hekimlerin verdiği cevaplar sayı ve yüzde ile tanımlanmıştır.

Bulgular. Ankete katılan uzmanlık öğrencilerinin ortalama yaşı, uzman olmayan diş hekimleri ve uzmanlardan anlamlı olarak düşük bulunmuştur $(P=0.003, P=0.038)$. Uzman olmayan diş hekimleri, baş-boyun bölgesinde gözlemlenen ekspoze kemiğin bisfosfonat tedavisi ya da radyoterapiye bağlı olabilme intimalini diğer gruplara göre daha az değerlendirmiştir $(P=0.048, P=0.008)$. Uzman ve uzmanlık öğrencilerine kıyasla uzman olmayan diş hekimleri, bisfosfonat kullanan hastaların radyolojik ve ağız içi bulguları hakkında daha az bilgi sahibi olduğunu belirtmiştir $(P=0.034)$.

Sonuç: Diş hekimlerinin bisfosfonatların kullanımı ve yan etkileri konusunda artan farkındalığı MRONJ'un önlenmesi için önemlidir. Diş hekimleri arasında MRONJ ve bisfosfonatlar ile ilgili bilincin artırılması için daha fazla çaba gösterilmesi ve hedef kitleye yönelik eğitim planları oluşturulması gerekmektedir.

Anahtar Kelimer. İlaca bağı çene osteonekrozları; bisfosfonatlar; diş hekimi; koruyucu hekimlik; anket 


\section{INTRODUCTION}

Bisphosphonates (BPs) are inorganic pyrophosphate analogues used for the treatment of osteo-porosis, osteopenia, hypercalcemia due to malignancy, multiple myeloma, Paget's disease, and solid tumour bone metastases (1). BPs are administered orally or intravenously and are grouped into two main classes: nitrogenous and non-nitrogenous. Nitrogen-containing BPs are more ef-fective than non-nitrogen-containing BPs $(1,2)$. During bone turnover, they are capable of bind-ing chemically to hydroxyapatite, and they have a half-life of almost 10 years. Both nitrogenous and nonnitrogenous forms inhibit osteoclastic activation by causing an alteration in the bone structure that reduces undesired events while enhancing the patient's quality of life (3-6). The Food and Drug Administration (FDA) first licensed alendronic acid for osteoporosis treatment in 1995. Later, the intravenous administration of zoledronic acid and pamidronic acid was ap-proved (7).

Just like any drug, BPs are associated with adverse effects such as nausea, acute renal failure, esophageal ulcers, bone-muscle pain, and allergic reactions $(1,2)$. In 2003, the first case of bisphosphonate-related osteonecrosis of the jaw (BRONJ) was presented in the literature, and numerous cases have been presented since then (8).

BRONJ is the most severe complication of BPs, and it is described as the presence of exposed bone that does not heal for 8 weeks with no history of craniofacial radiation exposure (9).

An updated classification was made in 2014, the complication was renamed as medication-related osteonecrosis of the jaw (MRONJ) (9). The new term 'MRONJ' comprises osteonecrosis of the jaw following the use of antiresorptive medications such as denosumab, bisphosphonate, sunitinib, bevacizumab, everolimus, or temsirolimus. Co-medication with drugs such as corti-costeroids presents an additional risk for MRONJ occurrence $(6,10,11)$.

Osteonecrosis risk increases according to the way of drug intake. Previous studies have shown that intravenous injection is associated with a higher risk of MRONJ occurrence $(12,13)$. More-over, $50-70 \%$ of BPs can reach to the bone following intravenous injection of the drug (1). The rates of MRONJ in cases following oral and intravenous administration are $7 \%$ and $93 \%$ respec-tively, as oral intake leads to less BP absorption in the bone (14).

The etiology has been discussed since the occurrence of the first MRONJ case. It was thought that dental diseases, local trauma, bone remodelling disruption, reduced angiogenesis, and in-fections can lead to a distorted bone microenvironment prone to osteonecrosis. It was considered that the reason for the high occurrence rates of BPs complication in the jaws was related to the high bone turnover rates of the jaws (15).

Every patient starting BP therapy should be scanned for dental foci of infection, and the focus, if present, should be treated before the therapy starts. Physicians prescribe BPs for many rea-sons; however, general dental practitioners (GDPs) and specialists (S) often do not have ade-quate knowledge of the patient's medication history, specifically regarding dosage, duration, and administration route (12).

Prevention of MRONJ is considered the best measure. Basic prevention strategies rely on medi-cal providers' knowledge of MRONJ risk factors. Yoo et al. reported that up to $71.1 \%$ of GDP were not aware that surgery in the dentoalveolar region was a risk factor for MRONJ in patients receiving BPs (16).

Although a conservative approach is widely accepted, an early surgical approach is becoming more popular as an MRONJ treatment option. Early intervention enables practitioners to control the lesion while it is still small. In most protocols, the affected bone is removed, and the defect is closed using a multiple-layer closure technique $(6,17)$. The latest procedures include admin-istration of platelet-rich plasma or the addition of mesenchymal stem-cell concentrate to pro-mote wound closure (18). Nevertheless, treatment is painful, and the primary goal should be the prevention of MRONJ occurrence (1). GDP, $\mathrm{S}$, and specialist trainees (ST) play a crucial role in this regard. Hence; it is a must to know about these drugs, their potential side-effects, preven-tion protocols, and convenient treatment options.

For the past 10 years, the Turkish Dental Association (TDA) has aimed to raise the awareness of physicians, GDP, dental students, and $S$ regarding BPs. Awareness can be enhanced via training, liaising with physicians for medication screening, preventative advice, and referrals. Increasing knowledge about the risks associated with BPs is essential; professionals in the dental commu-nity must be able to treat these patients and know when to refer advanced cases to specialists.

This study aimed to assess the knowledge of GDP, S, and ST regarding BPs and MRONJ and to optimize future training programs to bridge any knowledge gaps in this field. This study has a pivotal position, as it is the pioneer in collecting this data in Istanbul.

\section{MATERIAL AND METHODS}

This study was approved by Ethics Committee of Recep Tayyip Erdoğan University (Approval No: 2019/77) (Date of Approval 08/05/2019). A written informed consent was taken from the patients. A cross-sectional study consisting of a questionnaire survey was conducted. GDP, ST, and $S$ were included in the survey regarding their knowledge on BP and MRONJ. With support from the TDA, a self-administered questionnaire was prepared and shared among members via email. For the inclusion criteria, those who were active members participating in events or lectures organized by the association within the last 6 months were selected.

The survey was consisted of the questions on demographic 
information such as age, sex, specialty (if any), specialty graduation date, and years of work experience.

Six questions were used to determine participants' awareness of BPs and MRONJ.

To evaluate the findings, the Number Cruncher Statistical System (NCSS-2007) was used for statistical analysis (Utah, USA). In addition to descriptive statistical methods (mean and standard deviation), one-way analysis of variance was used for normally distributed variables, the Newman-Keuls multiple comparison test was used for sub-group comparisons, and the chi-square test was used to compare qualitative data. $p<0.05$ was considered statistically significant.

\section{RESULTS}

In this study, 131 of the 209 participants were GDP, 66 were ST, and 12 were $\mathrm{S}$.

The mean age of the ST group was significantly lower than the mean ages of the GDP and $S$ groups $(P=0.003, P=$ 0.038 ). The numbers of participants with $11-20$ and $>20$ years of work experience in the ST group were found to be significantly lower than in the GDP and S groups (Table 1).
When an exposed bone is observed in the head-and-neck region during a dental examination, GDP are less likely to think of BP administration and radiotherapy treatment than $\mathrm{S}$ or $\mathrm{ST}(\mathrm{P}=0.048, \mathrm{P}=0.008)$ (Table 2).

$S$ had more knowledge than ST or GDP of the indications for BP treatment in cases of multiple myeloma, Paget's disease, and hypercalcemia $(p=0.0001, p=0.0001$, and $p=0.004$, respectively). On the other hand, the GDP group was unfamiliar with the prescription reasons and responded "do not know" significantly more often than the ST and S groups $(p=0.002)$ (Table 3$)$.

In the GDP group, $31.82 \%$ reported that their patients under bisphosphonate administration had been referred to them by a physician. This percentage is significantly lower than that reported by the ST (51.52\%) and S (46.15\%) groups $(p=0.024)($ Table 4).

Among GDPs, $66.67 \%$ thought extraction of teeth with deep periodontal pockets should be performed before intravenous administration of BPs. Additionally, $70.45 \%$ thought extraction of teeth may cause periodontitis before IV administration of BPs. This percentage is significantly lower than the $S$ and ST groups $(p=0.001, p=0.030)$ (Table 5).

Tablo 1. Age, gender, and work experience

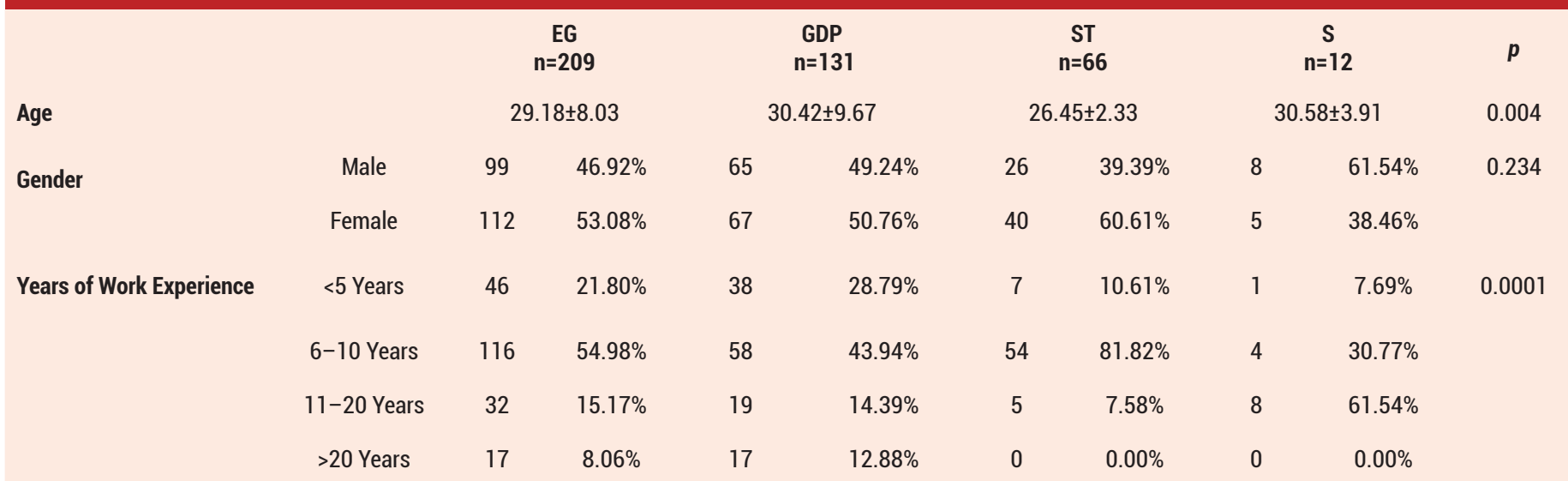

$\mathrm{EG}=$ entire group; $\mathrm{GDP}=$ general dental practitioner; $\mathrm{ST}=$ specialist trainee; $\mathrm{S}=$ specialist

Table 2. What would you assume as the cause when you observe an exposed-bone area during the dental examination of a patient who visits your clinic?

\begin{tabular}{|c|c|c|c|c|c|c|c|c|c|}
\hline \multirow[b]{2}{*}{ Bisphosphonate Use } & \multicolumn{2}{|c|}{$\begin{array}{c}\text { EG } \\
n=209\end{array}$} & \multicolumn{2}{|c|}{$\begin{array}{c}\text { GDP } \\
\mathrm{n}=131\end{array}$} & \multicolumn{2}{|c|}{$\begin{array}{c}\text { ST } \\
n=66\end{array}$} & \multicolumn{2}{|c|}{$\underset{n=12}{S}$} & \multirow{2}{*}{$\begin{array}{c}p \\
0.048\end{array}$} \\
\hline & 159 & $75.36 \%$ & 92 & $69.70 \%$ & 56 & $84.85 \%$ & 11 & $84.62 \%$ & \\
\hline Radiotherapy & 139 & $65.88 \%$ & 79 & $59.85 \%$ & 47 & $71.21 \%$ & 13 & $100.00 \%$ & 0.008 \\
\hline Osteomyelitis & 136 & $64.45 \%$ & 82 & $62.12 \%$ & 42 & $63.64 \%$ & 12 & $92.31 \%$ & 0.094 \\
\hline Dental Radix & 38 & $18.01 \%$ & 23 & $17.42 \%$ & 12 & $18.18 \%$ & 3 & $23.08 \%$ & 0.879 \\
\hline Do Not Know & 9 & $4.27 \%$ & 8 & $6.06 \%$ & 1 & $1.52 \%$ & 0 & $0.00 \%$ & 0.241 \\
\hline
\end{tabular}


Table 3. In which situations are bisphosphonate prescribed by physicians?

\begin{tabular}{|c|c|c|c|c|c|c|c|c|c|}
\hline \multirow[b]{2}{*}{ Physical Therapy } & \multicolumn{2}{|c|}{$\begin{array}{c}E G \\
n=209\end{array}$} & \multicolumn{2}{|c|}{$\begin{array}{c}\text { GDP } \\
n=131\end{array}$} & \multicolumn{2}{|c|}{$\begin{array}{c}S T \\
n=66\end{array}$} & \multicolumn{2}{|c|}{$\underset{n=12}{S}$} & p \\
\hline & 15 & $7.11 \%$ & 9 & $6.82 \%$ & 5 & $7.58 \%$ & 1 & $7.69 \%$ & 0.978 \\
\hline Osteoporosis & 170 & $80.57 \%$ & 103 & $78.03 \%$ & 56 & $84.85 \%$ & 11 & $84.62 \%$ & 0.484 \\
\hline Metastatic Tumour & 135 & $63.98 \%$ & 77 & $58.33 \%$ & 48 & $72.73 \%$ & 10 & $76.92 \%$ & 0.084 \\
\hline Multiple Myeloma & 7 & $3.32 \%$ & 2 & $1.52 \%$ & 2 & $3.03 \%$ & 3 & $23.08 \%$ & 0.0001 \\
\hline Paget's Disease & 12 & $5.69 \%$ & 6 & $4.55 \%$ & 2 & $3.03 \%$ & 4 & $30.77 \%$ & 0.0001 \\
\hline Hypercalcemia & 5 & $2.37 \%$ & 1 & $0.76 \%$ & 2 & $3.03 \%$ & 2 & $15.38 \%$ & 0.004 \\
\hline Cancer & 7 & $3.32 \%$ & 4 & $3.03 \%$ & 3 & $4.55 \%$ & 0 & $0.00 \%$ & 0.674 \\
\hline Do Not Know & 12 & $5.69 \%$ & 12 & $9.09 \%$ & 0 & $0.00 \%$ & 0 & $0.00 \%$ & 0.002 \\
\hline
\end{tabular}

$\mathrm{EG}=$ entire Group; $\mathrm{GDP}=$ general dental practitioner; $\mathrm{ST}=$ specialist trainee; $\mathrm{S}=$ specialist

Table 4. What is the primary reason for the visits of your patients who are under bisphosphonate administration?

$\begin{array}{cccc}\text { EG } & \text { GDP } & \text { ST } & \text { ST } \\ n=209 & n=131 & n=66 & n=12\end{array}$

\begin{tabular}{|c|c|c|c|c|c|c|c|c|c|}
\hline Halitosis & 66 & $31.28 \%$ & 42 & $31.82 \%$ & 19 & $28.79 \%$ & 5 & $38.46 \%$ & 0.771 \\
\hline Periodontal Problems & 97 & $45.97 \%$ & 61 & $46.21 \%$ & 32 & $48.48 \%$ & 4 & $30.77 \%$ & 0.501 \\
\hline Dental Extrusion & 70 & $33.18 \%$ & 41 & $31.06 \%$ & 26 & $39.39 \%$ & 3 & $23.08 \%$ & 0.365 \\
\hline Physician's Referral & 82 & $38.86 \%$ & 42 & $31.82 \%$ & 34 & $51.52 \%$ & 6 & $46.15 \%$ & 0.024 \\
\hline Pain & 103 & $48.82 \%$ & 56 & $42.42 \%$ & 37 & $56.06 \%$ & 10 & $76.92 \%$ & 0.022 \\
\hline Completion of Missing Teeth & 43 & $20.38 \%$ & 20 & $15.15 \%$ & 21 & $31.82 \%$ & 2 & $15.38 \%$ & 0.021 \\
\hline Dental Caries & 74 & $35.07 \%$ & 48 & $36.36 \%$ & 21 & $31.82 \%$ & 5 & $38.46 \%$ & 0.791 \\
\hline Dental Examination & 79 & $37.44 \%$ & 45 & $34.09 \%$ & 29 & $43.94 \%$ & 5 & $38.46 \%$ & 0.401 \\
\hline
\end{tabular}

$\mathrm{EG}=$ entire group; $\mathrm{GDP}=$ general dental practitioner; $\mathrm{ST}=$ specialist trainee; $\mathrm{S}=$ specialist.

Table 5. How should you design your treatment plan for patients before intravenous administration of bisphosphonates?

\begin{tabular}{|c|c|c|c|c|c|c|c|c|c|}
\hline \multirow[b]{2}{*}{ Endodontic Treatment of Apical Lesions } & \multicolumn{2}{|c|}{$\begin{array}{c}E G \\
n=209\end{array}$} & \multicolumn{2}{|c|}{$\begin{array}{c}\text { GDP } \\
\mathrm{n}=131\end{array}$} & \multicolumn{2}{|c|}{$\begin{array}{c}\text { ST } \\
n=66\end{array}$} & \multicolumn{2}{|c|}{$\begin{array}{c}S \\
n=12\end{array}$} & $\mathbf{p}$ \\
\hline & 88 & $41.71 \%$ & 57 & $43.18 \%$ & 26 & $39.39 \%$ & 5 & $38.46 \%$ & 0.852 \\
\hline Endodontic Treatment of Deep Caries Teeth & 103 & $48.82 \%$ & 65 & $49.24 \%$ & 30 & $45.45 \%$ & 8 & $61.54 \%$ & 0.563 \\
\hline Extraction of Teeth with Deep Periodontal Pockets & 159 & $75.36 \%$ & 88 & $66.67 \%$ & 59 & $89.39 \%$ & 12 & $92.31 \%$ & 0.001 \\
\hline Follow Up of the Embedded Teeth & 92 & $43.60 \%$ & 57 & $43.18 \%$ & 30 & $45.45 \%$ & 5 & $38.46 \%$ & 0.886 \\
\hline Extraction of the Teeth That May Cause Pericoronitis & 161 & $76.30 \%$ & 93 & $70.45 \%$ & 56 & $84.85 \%$ & 12 & $92.31 \%$ & 0.030 \\
\hline
\end{tabular}

$\mathrm{EG}=$ entire group; $\mathrm{GDP}=$ general dental practitioner; $\mathrm{ST}=$ specialist trainee; $\mathrm{S}=$ specialist. 
Compared to the S and ST groups, the GDP group displayed significantly less knowledge about radiological and intraoral examinations of patients undergoing BP therapy. Of the GDP group, $21.21 \%$ answered that they did not know what is worthy of notice during the examination; this result was significantly higher than that of the $S$ and ST groups ( $p=0.034)$. Pain, osteolysis, purulent discharge, alveolar bone sclerosis, and lamina dura sclerosis were considered worthy of notice in patients undergoing BP therapy by the $S$ and ST groups. Overall, the GDP group showed a lack of knowledge regarding BPs and MRONJ, and their results were significantly lower than those of the S and ST groups (Table 6).

Recognition of the increasing effects of BPs, when administrated intravenously, were lower in the GDP group $(56.82 \%)$ than the $S(76.92 \%)$ and ST $(80.31 \%)$ groups $(p=$ 0.0001 ). In addition, the GDP group displayed a lack of knowledge compared to the other groups regarding the nitrogen content of BPs $(p=0.005)$. The 'do not know' answer was significantly more common in the GDP group $(31.82 \%)$ than in the ST $(15.15 \%)$ and S $(23.08 \%)$ groups $(p=0.041)($ Table 7$)$.

Table 6. What is worthy of notice during an intraoral and radiological examination of patients undergoing bisphosphonate therapy?

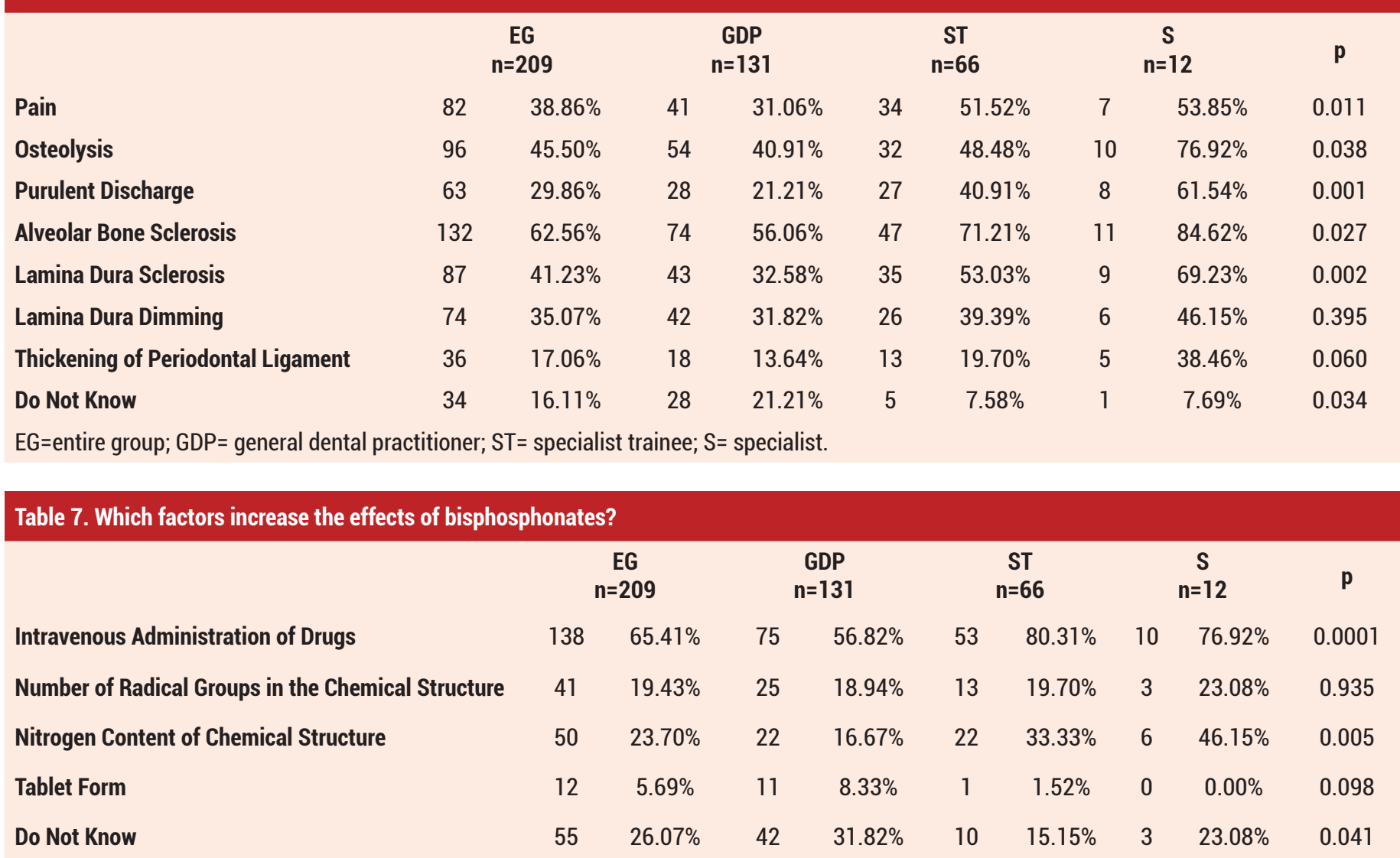

$\mathrm{EG}=$ entire group; $\mathrm{GDP}=$ general dental practitioner; $\mathrm{ST}=$ specialist trainee; $\mathrm{S}=$ specialist.

\section{DISCUSSION}

BPs have been commonly using in the management of skeletal complications of malignancy, including metastatic bone disease and hypercalcemia. Due to their noticeable benefits, they have become a standard in the management of skeletal complications, as well as in the management of osteoporosis and metabolic bone disease. In osteoporotic patients, BPs are administered in low doses, and they can effectively reduce the risk of bone fracture $(5,6,19)$.

Cases of age-related osteoporosis and administration of BPs have increased in Turkey. According to a study published in 2012, the prevalence of osteoporosis in women with 50 years of age and older is $3-4 \%$, and it approaches $30 \%$ at the age of 80 years. The study concluded that, in 20 years, cases of MRONJ would increase significantly due to a broader range of $\mathrm{BP}$ use (20).

Marx reported the first known case of MRONJ in 2003; since then, complications associated with BPs have been reported in many studies, and an increasing number of cases continue to be published worldwide (17-22).

Many articles on the awareness of MRONJ have been published, and, generally, low proportions of dental and 
medical professionals are aware of this condition. There is still inadequate knowledge regarding the prevention and management of MRONJ (2,13,16,23-25). Since treatment protocols are challenging, successful results cannot be achieved every time. Therefore, the current worldwide approach is to avoid the occurrence of MRONJ as much as possible. Education, as in everything else, is at the forefront of this subject. It is essential to educate dentists, physicians, and patients about BPs and their side effects.

In present study, it was aimed to determine the level of knowledge regarding BPs and their side effects among GDP, ST, and S, so that training strategies can be established to educate these professionals about MRONJ. It was aimed to ensure that treatment providers know the potential risks of MRONJ and when to consult a specialist.

According to the MRONJ classification published in 2014, symptoms of MRONJ can present in a variety of stages. Symptoms can be subjective or objective, and they may change the stage of MRONJ from Stage 0 to Stage 3 according to the clinical and radiological manifestations. Clinically, an exposed and necrotic bone can be observed with or without infection. In advanced cases, a pathological fracture may also co-exist with these manifestations (9).

In present study, when the GDP group observed the presence of an exposed bone, they were less likely than the $S$ and ST groups to think about BP use or osteoradionecrosis. One of the main reasons for this occurrence is that MRONJ is a relatively new complication, and dentists (without specialty training) who graduated before the year 2000 had no chance of acquiring adequate knowledge of this complication. They may consider the possibility of alveolitis (55.30\%) or radix $(17.42 \%)$ instead of MRONJ.

BPs are mostly administered intravenously to manage cancer-related conditions such as hypercalcemia due to malignancy, bone metastases, and lytic lesions of multiple myeloma. Oral administration is preferred for cases of Paget's disease and osteogenesis imperfecta, but the most common use is still for the treatment of osteoporosis and osteopenia $(1,2,4,6,7)$. According to results of present study, most GDP are not aware of the indications of BP use. It was also observed that physicians prefer to refer their patients to S or ST rather than GDP. As physicians prefer specialists for consultation, GDP often are not given opportunities to update their knowledge and skills.

On the other hand, the S group displayed more knowledge of the indications of BPs in cases of multiple myeloma, Paget's disease, and hypercalcemia than the ST and GDP groups. S, depending on their specialization, may have spent more time in training and might have encountered BP-administered patients or cases of MRONJ during their educational period.
Conversely, ST are less informed than S about the indications of BPs. During specialization training, trainees share the responsibility of cases with an expert or a lecturer. This may prohibit them from increasing their own knowledge. However, once they become a specialist and encounter such patients alone, they take full responsibility for the cases. It was believed that this encourages them to examine the topic deeply and in detail to avoid malpractice.

The risk of MRONJ increases with the use of nitrogencontaining BPs and in accordance with the way of drug intake. Studies indicate that intravenous injection of BPs causes a higher risk of MRONJ occurrence $(12,13)$. More than half of the given doses of BPs can reach the bone following intravenous injection. In present study, results showed that $S$ and ST are more aware than GDP regarding the increase in the influence of BPs when nitrogenous content is included or when the BPs are administrated intravenously. Moreover, in response to a question on the 'factors that increase the effect of BPs', GDP responded 'do not know' more frequently than S and ST.

Suppression of bone turnover, soft-tissue toxicity, infection, the antiangiogenic effect related to tissue ischemia, immunosuppression, and lack of vitamin D are the suspected causes of necrosis formation with the use of $\operatorname{BPs}(2,9,11)$. Oral surgery is the most critical risk factor for the development of MRONJ. Following the tremendous rise in dental implant procedures, the number of tooth extractions has also increased. In a study of cancer patients receiving zoledronic acid, tooth extraction was associated with a risk of MRONJ 16 times higher than in those without tooth extraction (26). In areas like the maxillary and mandibular tori, which have a high risk for deterioration of the integrity of the mucosa, the risk of MRONJ is also high. Therefore, it is critical to perform an intraoral and radiological examination before the use of BPs. To prevent MRONJ occurrence, endodontic treatment, periodontal treatment, or extractions should be performed before BP administration. Since BPs have a half-life of approximately 10 years in bone, treatment plans should be long-lasting $(1,2,9)$. In the present study, it was observed that the GDP group showed a lower preference for extraction of the teeth that may cause pericoronitis and extraction of teeth with deep periodontal pockets than the S and ST groups. This may indicate that dental practitioners are having difficulty taking the initiative to perform the correct treatment.

Treatment objectives in patients receiving BPs are to eliminate pain, control infection of the soft/hard tissues, and minimize the occurrence of bone necrosis. Aching bone pain in the jaw, odontalgia not explained by an odontogenic cause, loosening of teeth, exposed and necrotic bone, or fistulas are the clinical findings of MRONJ.

Additionally, alveolar bone loss, trabecular bone pattern changes, and thickening of the lamina dura or periodontal ligament are the radiological findings of MRONJ (27-31). 
In present study, participants in the GDP group stated they did not know what is worthy of notice in the cases of patients under BP treatment.

According to Yoo et al., $71.1 \%$ of the dentists who participated in their survey stated that they were unaware of the effects of invasive dental procedures on MRONJ (16). Following this finding, the results of present study showed that GDPs in Turkey do not have adequate knowledge of the theoretical and therapeutic terms. Their awareness of MRONJ treatment guidelines was low. In an aging society with more patients taking osteoporosis medication, dentists have to acknowledge, prevent, and respond correctly to osteonecrosis of the jaw. The findings of present study should be handled with caution. Nonetheless, GDP should suspect MRONJ when they observe a non-healing wound after invasive treatment. The authors believed that lack of specialization and not attending updating courses or otherwise furthering their education could be the reason of this MRONJ knowledge deficiency.

While reading scientific articles, dentists are mostly focused on visual information (30). Therefore, for a lasting effect, more areas should be dedicated to photos and graphics in articles about BPs and MRONJ. In the future, interactivity of digital communication would also produce an alternative to formal literature; dentists will be able to customize their research according to their needs. An emphasis on digital information may raise awareness about BPs more quickly.

In addition, physicians and dentists are organizationally separated in Turkey, implying that interprofessional exchanges only occur on a voluntary basis. The move to unite these organizations may be an important step.

\section{CONCLUSION}

Limitations of this survey include its cross-sectional nature, a low number of participants, and regional data. However, despite these limitations, the results support the conclusion that stronger educational efforts are needed to disseminate information regarding BPs and MRONJ. Future researches can be conducted with a bigger number of participants. In addition, more studies should place focus on the physicians and medical doctors to reveal their awareness and knowledge about BPs and MRONJ, as they are responsible for the occurrence of MRONJ.

Dental associations and professional organizations are responsible for a graduated dentist's training and improvement following graduation. However, specialization and postgraduate training is under the responsibility of universities. Since the treatment of MRONJ is not related to all areas of dental specialization, those who receive training in non-surgical specialties may not be aware of the issue. In conclusion, the authors recommend that topics such as BPs and MRONJ be included in all dental specialization programs. The findings of present study suggest that greater educational efforts should be made to promote the knowledge of this pathology, especially for GDP.

Financial disclosures: All authors report no financial interests or potential conflicts of interest.

Conflict of Interest: The authors declare that they have no competing interest.

\section{Ethical approval}

Recep Tayyip Erdogan University - NO:2019/77

\section{REFERENCES}

1. Sigua-Rodriguez EA, da Costa Ribeiro R, de Brito AC, et al. Bisphosphonate-related osteonecrosis of the jaw: a review of the literature. Int J Dent 2014;2014:192320.

2. Masson DR, O'Callaghan E, Seager M. The knowledge and attitudes of North Wales healthcare professionals to bisphosphonate associated osteochemonecrosis of the jaws. JDOH 2009;10:175-83.

3. Bauer JS, Beck N, Kiefer J, et al. Awareness and education of patients receiving bisphosphonates. J Craniomaxillofac Surg 2011;40:277-82.

4. Liu J, Huang W, Zhou R, et al. Bisphosphonates in the treatment of patients with metastatic breast, lung, and prostate cancer: a meta-analysis. Medicine (Baltimore) 2015;94:1-4.

5. Tanna N., Steel C., Stagnell S., et al. (2017). Awareness of medication related osteonecrosis of the jaws (MRONJ) amongst general dental practitioners. BDJ 2017;222:121-5.

6. Voss PJ, Poxleitner P, Schmelzeisen R, et al. Update MRONJ and perspectives of its treatment. J Stomatol Oral Maxillofac Surg 2017;118:232-5.

7. Wang J, Goodger NM, Pogrel MA. Osteonecrosis of the jaw associated with cancer chemotherapy. J Oral Maxillofac Surg 2003;61:1104-7.

8. Pazdur R. Postmarketing safety review: Bisphosphonates. Food and Drug Administration, Office of Drug Safety. http://www.fda.gov/ohrms/dockets/ac/05/briefing/20054095b2_03_02-fda-tab1.doc; Accessed January 2017.

9. Ruggiero SL, Dodson TB, Fantasia J, et al. American Association of Oral and Maxillofacial Surgeons position paper on medication-related osteonecrosis of the jaw 2014 update. J Oral Maxillofac Surg 2014;72:1938-56.

10. Hamadeh IS, Ngwa BA, Gong Y. Drug induced osteonecrosis of the jaw. Cancer Treat Rev 2015;41:455-64.

11. Walter C, Laux C, Sagheb K. Radiologic bone loss in patients with bisphosphonate-associated osteonecrosis of the jaws: a case-control study. Clin Oral Investig 2014;18:385-90.

12. Fantasia JE. Bisphosphonates-what the dentist needs to know: practical considerations. J Oral Maxillofac Surg 2009;67:53-60.

13. Al-Mohaya MA, Al-Khashan HI, Mishriky AM, et al. Physicians' awareness of bisphosphonates-related osteonecrosis of the jaw. Saudi Med J 2011;32:830-5

14. Hong JW, Nam W, Cha IH, et al. Oral bisphosphonate-related osteonecrosis of the jaw: the first report in Asia. Osteoporos Int 2010;21:847-53. 
15. Beninati F, Pruneti R, Ficarra G. Bisphosphonate-related osteonecrosis of the jaws (Bronj). Med Oral Patol Oral Cir Bucal 2013;18:e752-e758.

16. Yoo JY, Park YD, Kwon YD, et al. Survey of Korean dentists on the awareness of bisphosphonate-related osteonecrosis of the jaws. J Investig Clin Dent 2010;1:90-5.

17. Lemound J, Eckardt A, Kokemüller H, et al. Bisphosphonateassociated osteonecrosis of the mandible: reliable soft tissue reconstruction using a local myofascial flap. Clin Oral Investig 2012;16:1143-52.

18. Norholt SE, Hartlev J. Surgical treatment of osteonecrosis of the jaw with the use of platelet-rich fibrin: a prospective study of 15 patients. Int J Oral Maxillofac Surg 2016;45:1256-60.

19. Aljohani S, Fliefel R, Ihbe J,et al. (2017). What is the effect of anti-resorptive drugs (ARDs) on the development of medication-related osteonecrosis of the jaw (MRONJ) in osteoporosis patients: a systematic review. J Craniomaxillofac Surg 2017;45:1493-502.

20. Tuzun S, Eskiyurt N, Akarirmak $U$, et al. Incidence of hip fracture and prevalence of osteoporosis in Turkey: the FRACTURK study. Osteoporos Int 2012;23:949-55.

21. Marx RE. Pamidronate (Aredia) and zoledronate (Zometa) induced avascular necrosis of the jaws: a growing epidemic. J Oral Maxillofac Surg 2003;61:1115-7.

22. Marx RE, Cillo JE, Ulloa JJ. Oral bisphosphonate-induced osteonecrosis: risk factors, prediction of risk using serum CTX testing, prevention, and treatment. J Oral Maxillofac Surg 2007;65:2397-410.

23. Ho A, Ahn JH, Ameerally P. Awareness of bisphosphonaterelated osteonecrosis of the jaws in healthcare professionals.
Face Mouth Jaw Surg 2013;3:21-8.

24. López-Jornet P, Camacho-Alonso F, Molina-Miñano F, et al. Bisphosphonate-associated osteonecrosis of the jaw. Knowledge and attitudes of dentists and dental students: a preliminary study. J Eval Clin Pract 2010;16:878-82.

25. Muthukrishnan A, Al-Ismail S, Bertelli G, Browne P. MRONJ risk reduction pathway- 360-degree survey. BDJ 2017;222:386-90.

26. Kyrgidis A, Vahtsevanos K, Koloutsos G, et al. Bisphosphonate-related osteonecrosis of the jaws: a casecontrol study of risk factors in breast cancer patients. Jpn J Clin Oncol 2008;26:4634-8.

27. Bamias A, Kastritis E, Bamia C, et al. Osteonecrosis of the jaw in cancer after treatment with bisphosphonates: incidence and risk factors. J Clin Oncol 2005;23:8580-7.

28. Marx, R. Oral, and intravenous bisphosphonate-induced osteonecrosis of the jaws: history, etiology, prevention, and treatment (2nd ed). Hanover Park, IL: Quintessence Publishing; 2003.

29. Sinningen $K$, Tsourdi $E$, Rauner $M$, et al. Skeletal and extraskeletal actions of denosumab. Endocrine 2012;42:5262.

30. Chambers DW, Lyon LJ. How dentists read a technique article: a grounded theory investigation. J Prosthodont 2017;26:682-687.

31. Çebi AT. Knowledge and awareness of dentists working at a dental hospital in a city bbout bone osteonecrosis due to medication. ACU Sağlık Bil Derg 2019;10:438-42. 